\title{
Policing Life and Death
}

RACE, VIOLENCE, AND RESISTANCE IN PUERTO RICO

\author{
Marisol LeBrón
}

\section{따}


University of California Press, one of the most distinguished university presses in the United States, enriches lives around the world by advancing scholarship in the humanities, social sciences, and natural sciences. Its activities are supported by the UC Press Foundation and by philanthropic contributions from individuals and institutions. For more information, visit www.ucpress.edu.

University of California Press

Oakland, California

(C) 2019 by Marisol LeBrón

Library of Congress Cataloging-in-Publication Data

Names: LeBrón, Marisol, author.

Title: Policing life and death : race, violence, and resistance in Puerto Rico / Marisol LeBrón.

Description: Oakland, California : University of California Press, [2019] | Includes bibliographical references and index. |

Identifiers: LCCN 201804OI29 (print) | LCCN 2018044I 43 (ebook) | ISBN 9780520971677 (ebook) | ISBN 9780520300163 (cloth : alk. paper)| ISBN 9780520300170 (pbk. : alk. paper)

Subjects: LCSH: Discrimination in law enforcement-Puerto Rico-History-2oth century. | Discrimination in criminal justice administration-Puerto Rico-History-2oth century. |

Police-community relations-Puerto Rico-History-2oth century.

Classification: LCC HV8174.A3 (ebook) | LCC HV8174.A3 L 432019 (print) | DDC $363.2 / 3097295-\mathrm{dc} 23$

LC record available at https://lccn.loc.gov/2018040I29

Manufactured in the United States of America

$\begin{array}{llllllllll}28 & 27 & 26 & 25 & 24 & 23 & 22 & 21 & 20 & 19\end{array}$

$\begin{array}{llllllllll}10 & 9 & 8 & 7 & 6 & 5 & 4 & 3 & 2 & \text { I }\end{array}$ 
Policing Life and Death 

For my mother - this would not have been possible without you. 
